\title{
El Problema del Bilingüismo en el Perú
}

La diversidad de lenguas en un país es su más poderosa fuerza de fractura y dispersión colectivas. Las naciones multilingües, como en el ejemplo clásico de Suiza, persisten no porque su pluralidad idiomática haya dejado de ser funesta, sino porque alli han surgido factores de cohesión excepcionales, principalmete de índole geográfica y política, que no siempre aparecen y que han sido capaces de compensar aquella tremenda desunidad. El largo equilibrio de Suiza no tiene tampoco ninguna garantía de persistir si nuevas corrientes de inducción étnica o política superan las tradicionales del país. Mucho más asegturado estaría su destino si al interior de sus valles y en to elevado de sus riscos y mesetas floreciese una lengua propia, perfil de un alma definida, y si al exterior hubiese irradiado una literatura tan rica como la de los pueblos escandinavos, no mayores en importancia. La lengua unifica porque ella es el vaso trasparente en que se deposita la conciencia común. No sólo es el instrumento de lá comunicación social. Es al mismo tiempo un arquetipo de lógica y de belleza. La morfología y la sintaxis son los límpidos escorzos de una concepción soñada por el 
pueblo desde tiempos legendarios. Manifiestan su fantasía, sus hábitos mentales, su afectividad, su energía, su ideal de música. Por eso, entre los lazos más fuertes de unión nacional está el idioma y el bilingüismo es, en consecuencia, un incentivo de disolución.

Pero los estudios modernos sobre bilingüismo no sólo destacan el valor del lenguaje como nexo social; lo destacan también como valor de inteligencia y de capacitación psicológica. Por el lenguaje el hombre es homo loquens y esto lo hace unidad del grupo social; pero asimismo por el lenguaje es homo sapiens y esto to hace señor del pensamiento y de la vida interior. Fuera del campo de la vida en común, en el simple proceso del pensamiento aislado, con relación a cada persona, el bilingtiismo es un elemento re= tardatario. Lo ha demostrado así la psicología experimental y fué la única conclusión clara y definitiva de la Conferencia Internacional de Bilingüismo celebrada en Luxemburgo. A esta Conferencia concurrieron, de modo principal, educadoresyilstissonenciảe se erefirieron a observaciones científicas en paises bilingiies Les nzás notables trabajos fueron los de Nicolás Ries, sobre el problema en Luxemburgo; John Hughes y J. D. Saer sobre el problema en el país de Gales; O Decroly, sobre el problema en Bélgica; Th. Mockli, sobre el problema en Suiza; Alejandro Gali, sobre el problema en Cataltña; y comprendieron no solamente informaciones y apreciaciones de carácter general, sino con referencia a particulares elementos, como la intervención de la familia, de la lengua oficial, de los dialectos, de la aptitud para las lenguas, de la afectividad, del carácter, etc. El campo de experimentación fué la escuela. Ningún otro sitio es más a propósito por lo accesible a esta clase de investigaciones, pues en la escuela se congregan sujetos de distinta procedencia y condición, todos los cuales poseen una 
naturaleza en proceso de crecimiento y transformación. Nada está allí definitivamente formado y todo se manifiesta de modo espotáneo y natural. La participación del lenguaje en la esencia del pensamiento se revela con una sorprendente claridad. Todas las verificaciones de los últimos tiempos y particularmente las de Piaget, han sido realizadas en niños que expanden al mismo tiempo su inteligencia y su expresión. De tan precioso campo, han surgido algunos datos ciertos $y$ ellos nos hacen ver los contratiempos siempre dolorosos y a veces dramáticos que sufren los escolares sujetos a la influencia de dos lenguas.

El fenómeno más interesante para nosotros es el que se produce en donde hay una lengua regional indígena que no es apta para lá cultura por su carencia de textos, en la cual no está escrita ni la ley ni la ciencia, ni siquiera el letrero de la calle y que se bate en retirada agónica frente a una lengua moderna y culta, dotada, además, del imperio político. Es el caso del galés, en Inglaterra, según los estudios de Saer y Hughes ( I). Persigamos estas sugestivas investigaciones en su proceso y ensils] iresultados.e Paramejor comprensión, aclaremos que, en casos semejanteso se llama primera bengua a la aprendida de la madre y cue constituye el tejido mental de la primera edad; y segunda lengula a la que más tarde se aprende, sea con los juegos, con el contacto de la calle, con la educación escolar o con cualc|uier otro motivo posterior. La primera lengua se caracteriza por su gran fuerza psicológica: es un substracto íntimo c|ue ha acompañado al niño en su expansión inicial hacia el espacio y la luz exteriores, está saturado de intimismo cálido y dilecto, constituye un báculo del que no se puede desprender en el incierto camino que sigue

(1) "Estudio de los Problemas Psicológicos del Bilingüismo" por J. D. Saer. "Los Estudios sobre el Bilingüismo en el País de Gales" por John Hughes. 
hasta los nueve años. Hasta esta edad el niño conoce pocas palabras. Su reducido vocabulario se incrementa escasamente porque más que nuevas palabras le interesa aclarar las que posee y cuyo significado no encuentra definido ni seguro. Hacia lo nueve años y en coincidencia con un más vigoroso desarrollo mental, se halla en aptitud de ampliar su propia lengua y recibir el ingreso de otra. La segunda lengua se caracteriza por su significación cultural, política, económica y práctica. Es universal, forma una atmósfera luminosa de técnica y de belleza, conduce rápidamente a los secretos de la ley y de la propia defensa, iguala al nivel de las clases más poderosas, facilita el trabajo y es útil para la circulación por todos los caminos de la vida. Resulta necesario y natural irrumpir en ella, aunque la primera permanezca yacente en la subconciencia. Tarde o temprano llega el momento en que el niño, el adolescente 0 el adulto aprenden la segunda lengua. Podrán darse al respecto varios casos: las dos lenguas se saben y se practican, cada una en su esfera y en su oportunidad; la segunda lengua, por haberse aprendido en tierna edad, vence adadprimera y esta se olvida; la primera lengua yence aplacegunda $y_{1}$ el sujeto no conoce de ésta sino las frases o palabras indispensables para sus relaciones con gentes de lengua oficial. Podemos considerar estos y otros matices sobre el fenómeno, pero que son iguales para las conclusiones de la observación psicológica. En todos los matices, los sujetos tienen una característica general: son bilingües en contraposición a los sujetos monoglotas o sea los que no han tenido nunca relación sino con una sola lengua. Ahora bien, ¿Cuál es el efecto del bilingüismo sobre el espíritu del niño? El bilingüismo produce retardo mental y hace descender el cociente de aprovechamiento escolar. Después de examinar un número suficiente de niños tanto bilingïies como monoglotas se llega a es- 
ta conclusión. Así lo demuestran pruebas tan sencillas como los tests de dextralismo (orientación a la derecha y a la izquierda), tests de ritmo, tests de vocabulario y tests de composición. Los cuestionaros estaban formulados en la segunda lengua. Formulados en la primera, el resultado era mejor, pero sin superar el resultado de los niños monoglotas. Experimentados en adultos bilingües, aún de educación universitaria, se confirman los resultados fundamentales. Bertrand Russell compara las palabras con flechas que se disparan sobre un blanco determinado. El blanco tiene un centro, pero también una vasta zona de aros concéntricos. Pues bien, a medida que se habla mejor se va pasando de los aros al centro. El hombre más expresivo es aquel que tiene una puntería exquisita para acertar con las palabras precisas sobre el blaneo de su objetivo intelectual. Pero nunca se llega a la absoluta precisión. La misma palabra, puesta en boca de dos personas monoglotas de igual cultura, tiene que ofreces variantes por la afectividad y el contenido ideológico. El centro del blanco no es pues un punto sino un núcleo de discreta amplitud.S Y si esa discrepancia se producēoentre upersonlis nnonoglotas de igual cultura, ¿cuál no será entre una persona bilingüe de origen campesino y cultura rudimentaria y una persona monoglota de origen urbano y cultura superior? A la primera todo tiene que serle hostil. Utiliza un instrumento de expresión que no le es propio, que lo siente áspero e insumiso y lo utiliza en un medio en que la acción de personas mas sabias y poderosas comprime desde el punto de vista espiritual. Si1 incertidumbre será dolorosa, sus fallas le producirán confusión y cuando son objeto de burla, como a menudo pasa, le dejarán -humillado y triste. De estas circunstancias se origina el complejo de inferioridad que descorazona por la sensación de que algo esencial falta para el cumplimien- 
to de los cometidos sociales que a todos nos incumben (sentiments d'incompletude de Janet). De los individuos, este efecto perturbador pasa a los pueblos y fácilmente el país queda dividido en sectores antagónicos, separados por un abismo de incomprensión y desconfianza. Esto sucede en el país de Gales principalmente entre el aldeano bilingüe galés y el esquire (caballero de habla inglesa), pero la regla es extensiva a todos los países y la podemos aplicar al Perú, meditando con preocupación nacionalista y humana.

En el momento de la conquista española, en el Perú se hablaban distintas lenguas indígenas sobre las cuales se extendía como un manto político el universal runasimi o quechua, lengua imperial de los incas. Sabemos por los cronistas de Indias que los ejércitos cuzqueños llevaban su idioma y lo imponían como necesidad de Estado en las regiones incorporadas, de tal modo que en algunos lugares éste había logrado desplazar por completo a la lengua nativa, en otros se hållab̉a superpulestā sobre aquella y en otros era apenas un estrato leve delivocabulario oficial para las relaciones con el vencedor. En su excelente libro ( I), Pedro M. Benvenutto Murrieta nos brinda una síntesis sobre aquel panorama. El quechua tenía su ámbito propio en las cuencas de los ríos interandinos Urubamba, Apurímac, Mantaro, Marañón y parte de la del Huallaga, con las variedades dialectales que corresponden a tan amplia zona, principalmente el huanca del Mantaro y el chinchaysuyo del Marañón y del Huallaga. El aymara, con centro en la meseta del Collao, se extendía por el sureste hasta Cochabamba en la actual Bolivia y por el noroeste hasta Canta, en el actual departamento de Lima, a través de una franja de

(1) Pedro M. Benvemutto Murrieta. El Lenguaje Peruano. 
penetración que comprendía tierras de Cailloma, Canga1lo, Huamanga, Lucanas, Huancavelica, Yauyos y Huarochirí. El yunga se hablaba en la costa desde. Lima hasta el golfo de Guayaquil, diferenciado en innumerables dialectos o alternado, tal vez, con otras lenguas independientes, en un panorama lingüístico poco estudiado y difícil de apreciar por su completa extinción al presente. Entre esos dialectos están el sec de Piura, el quignam de Lambayeque y Chiclayo y el muchic de Trujillo. El puquina abarcaba la costa sur, hasta las riberas del lago Titicaca y el desierto de Atacama. En la cuenca del Huallaga predominaba la lengua cholona. Hacia la ignota región de las selvas amazónicas se usaban numerosos dialectos o lenguas emparentadas que en gran parte sobreviven tales como el campa, el aguarico, el machignenga, el huaraya, etc., y que en época reciente han sido individualizados hasta el número de ochentaidós.

E1 mosaico linguístico era, pues, profuso y abigarrado y la lengua oficial no había logrado darle la unidad necesaria. Esta es una circunstancia que hay que tener en cuenta porque siseoquisiera aesolvere el problema del bilin. güismo pertuno por elpequilibrio yo convivencia de dos lenguas oficiales, se promovería de inmediato la segunda cuestión: ¿Cuál lengua indígena es la que debe subsistir en igualdad de prerrogativas con el castellano? ¿Por qué el quechua del Cuzco en vez del huanca de Junín o el chinchay'suyo del Marañón? ¿Y por qué no se va a dar vida. oficial a los dialectos florestales? La concesión a una lengua tendría, para ser justa, que extenderse a todas las demás y a sus respectivos dialectos, con lo que el Perú sería una auténtica Babel y no nos entenderíamos de una provincia a otra con el consiguiente despedazamiento de la unidad nacional.

El castellano es la lengua oficial que reemplazó al que- 
chua en su esfuerzo de integración lingüística. Desde el punto de vista político y cultural tenía una superioridad definitiva sobre las lenguas aborígenes. Llegaba con un nuevo Estado y con una nueva civilización. No obstante, su triunfo no fué de inmediato ni general. Diversos factores de orden histórico y sociológico determinaron que el castellano no penetrase a las islas quechuas y aymaras del campesinado indio disperso en las anfractuosidades de los Andes. De tal modo que el castellano cubre al país pero sobre él irrumpen, a manera de un archipiélago que fuese testimonio de tierras desaparecidas, rosarios de manchas isoglósicas. Estas no se pueden explicar sino por una inercia de la vida que sobre aquellas mismas petrificaciones de lenguaje perennizó el retardo de la cultura. Los indios que hablan quechua y aymara se quedaron con sus idiomas arquelógicos como se quedaron con suis cultivos, con su gregarismo, con su higiene, con sus supersticiones y con su alma de las edades primitivas. La explicación de por qué subsisten las lenguas aborígenes en ta sierra peruana marginadas en todos sentidos por el castellano, es una explicación que no puede separarse de la subsistencia integral de un estado de cultura. Hay en cambio indios que hablan castellano desde hace varias generaciones; pero su condición de progreso linguiístico está en consonancia con su progreso cultural y con su asimilación a la vida y al ritmo del país. Como el progreso no puede detenerse por más que avance con la lentitud de un glaciar, poco a poco inundará como una onda el Perú y con él el castellano anegará y suprimirá todas las islas lingüísticas que restan en los Andes. El panorama actual de aquellos idiomas aborígenes es el siguiente: en la costa, la región de las grandes ciudades, de las industrias, de las vías de comunicación fáciles y del 
ritmo moderno de la vida, las lenguas indígenas han desaparecido. Los habitantes de las campañas, muchos de ellos indios de pura sangre, hablan solamente castellano desde hace varias generaciones. En la región de la sierra, de cultura desigual, con población dispersa y a veces clausurada dentro de valles inaccesibles o altos páramos, se habla castellano en las ciudades y quechua en la mayor parte de las campañas, con el núcleo más extenso y vigoroso en el departamento del Cuzco. La regla no puede ser absoluta porque a veces se escucha hablar quechua a gentes de estratos inferiores de las ciudades o en los poblachos dispersos por los campos y también porque de pronto hablan estas lenguas mestizos y blancos envueltos en una atmósfera regresiva, pero se cumple cono la ley general, en cuanto a primera lengua. Es diferente el caso de gentes de las ciudades que por razones de comercio con las gentes del campo hablan el quechua como segunda lengua. Pero aun en las mismas campañas de los Andes el quechua está mellado por la penetración castellanizante. Desde el Cuzco hacia el norte hay una declinación de su amplitud y de su fuerza. El departamento de Junín, en el centro, con sus industrias modernas, sus ciudades comerciales y sus numerosas escuelas, es un campo de lucha de las lenguas muy interesante y promisor. Cajamarca, en el norte, tiene provincias enteras donde sólo se habla castellano como Jaén, Chota y Cutervo. En sus demás provincias, el castellano gana terreno día a día. La lucha no se manifiesta únicamente por la eliminación del quechua sino por la relajación morfológica y sintáctica de éste bajo la influencia del castellano. Así sucede con el quechua de Ancash y de Huánuco que ha tomado del castellano la conjunción $y$. En el "Apunchic Jesucristoc Chuscu Evangeliocuna" o sean "Los Cuatro Evangelios" 
traducidos al quechua de los departamentos de Huánuco y Ancash por la "British and Foreing Bible Society" en I92.3, por razones de proselitismo, se condesciende con estas relajaciones que son un síntoma de agonía próxima. Las lenguas no mueren porque admiten el vocabulario de otras y al contrario, como en el ejemplo del inglés moderno, éste puede ser un aspecto de su carácter imperial. Pero las lenguas sí mueren porque ceden en sus esencias morfológicas y sintácticas, reductos vertebrales de su organismo, aunque sea en detalles que aparentemente no tienen volumen como sus nexos y partículas. El aymara de Puno y el cholona de San Martín se encuentran en iguales condiciones que el quechua del resto de la sierra y lo mismo sucederá con los dialectos florestales de la montaña cuando la vida nacional avance hacia su ámbito, ahora casi inexplorado. Estas no son apreciaciones sentimentales, originadas por afán hispanizante o por menosprecio a los valores terrígenos. Son simples observaciones objetivas, basadas en la ciencia idionática e en lárealidad seruana. Pero si quisiéramos dejarnos guiar poli el sentimiento, lo que afirmanıos tampoco variaría porque antes que un afecto romántico por las lengtuas aborígenes nos interesa el indio que las habla. El bien entendido afecto por el indio tiene que empeñarse, con viva impaciencia, en su rápida castellanización .Esto puede no convenirle a políticos, a estetas o a filólogos, pero le conviene al Perú y sobre todo, le conviene al indio. Sin embargo, una falsa solución puede darse que es capaz de impresionar y que consistiría en fomentar el bilingüismo más o menos con el siguiente razonamiento: está bien que el indio aprenda el castellano para su defensa, su cultura y su comercio, pero que no olvide el quechua para el hogar, para la amistad y para la fiesta ín- 
tima de la vida. Semejante manera de pensar no resuelve el problema porque el indio bilingüe sigue siendo el indio inferior. Lo sabemos por las pruebas científicas a que hacemos alusión al comienzo de este artículo: aunque se aprenda bien una segunda lengua, la primera subsiste como un cauce mental que no deja libre el pensamiento y el hombre bilingüe es un retardado psíquico, en irremisible e injusto desnivel con el resto de sus conciudadanos.

De un lado tenemos, pues, el espectáculo de una lucha de lenguas en que el castellano, lenta pero seguramente, bate a los dialectos aborígenes; y de otro el de hombres, compatriotas nuestros, que por vivir un estadio pretérito de la cultura, hablan lenguas aborígenes o hablan el castellano como segunda lengua, en desigualdad, en ambos casos, con los otros habitantes del Periu. Debemos fomentar en consecuencia, la unidad lingüística nacional sobre la base del castellano, idiona peruano desde hace cuatrocientos años. La generación monoglota de lengua indígena debe

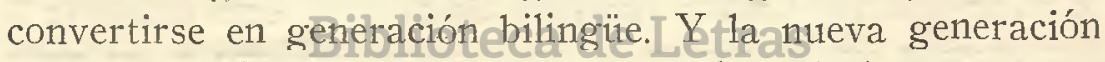
debe convertirse sligeneración mogoglota de lengua castellana. Felizmente el Perú marcha rápidamente al porvenir y el proceso tiene todos los síntomas de una aceleración próxima. En ello nos da ejemplo México, país no sospechoso de reaccionario, cuyos maestros tienen entre las cosas más bellas y positivas de su "Ideario", respetar y amar las lenguas aborígenes, en cuanto son floraciones de un pasado ancestral, pero proceder a la rápida castellanización de los indios.

JoSÉ JiMÉnez BORJA. 